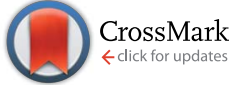

Cite this: RSC Adv., 2017, 7, 4563
Received 14th November 2016 Accepted 22nd December 2016

DOI: 10.1039/c6ra26754h

www.rsc.org/advances

\section{Fenton-like degradation of 2,4-dichlorophenol using calcium peroxide particles: performance and mechanisms}

\author{
Hefei Wang, ${ }^{\text {ab }}$ Yongsheng Zhao, ${ }^{\text {ab }}$ Yan Su, ${ }^{\mathrm{c}}$ Tianyi Li, ${ }^{\text {ab }}$ Meng Yao ${ }^{a}$ \\ and Chuanyu Qin*ab
}

The degradation process of 2,4-dichlorophenol (2,4-DCP) in aqueous solution by a Fenton-like system using calcium peroxide $\left(\mathrm{CaO}_{2}\right)$ particles as a source of solid $\mathrm{H}_{2} \mathrm{O}_{2}$ was investigated. EDTA was added to the system to chelate iron and promote the Fenton-like reaction. The results show that 2,4-DCP can be readily degraded in a $\mathrm{CaO}_{2}$ /EDTA-chelated Fe(॥) system. Compared with an $\mathrm{H}_{2} \mathrm{O}_{2}$ /EDTA-chelated Fe(॥) system, 2,4-DCP degradation showed a moderate reaction rate owing to the slow dissolution process of the $\mathrm{CaO}_{2}$ particle. Complicated degradation kinetics were observed and the possible reason was revealed. The initial amount of EDTA chelated iron lost during the Fenton-like reaction was in the range $20-30 \%$. The effects of different reaction parameters, such as initial $\mathrm{pH}, \mathrm{CaO}_{2}$ dosage and amount of EDTA-chelated iron, on 2,4-DCP degradation were studied. According to the identification of dominant reactive species and degradation intermediates, a possible theoretical degradation pathway of 2,4-DCP was proposed.

\section{Introduction}

The Fenton-like process, which was developed from traditional Fenton technology, provides a promising alternative for the oxidative treatment of contaminated soil and groundwater. Conventional Fenton's reagent involves the catalyzed decomposition of hydrogen peroxide $\left(\mathrm{H}_{2} \mathrm{O}_{2}\right)$ by $\mathrm{Fe}$ (II) to form a suite of highly active species, including the hydroxyl radical ( $\left.\mathrm{HO}^{\circ}\right)$, perhydroxyl radicals $\left(\mathrm{HO}_{2}^{\cdot}\right)$, superoxide radical anions $\left(\mathrm{O}_{2}^{-}\right)$, and hydroperoxide anions $\left(\mathrm{HO}_{2}{ }^{-}\right)$(reaction (1)-(8)). ${ }^{1-6}$ Among them, $\mathrm{HO}^{\circ}$ generated via reaction (1) is the main species. It has a high oxidation potential $(2.76 \mathrm{~V})$ and can react indiscriminately with most organic contaminants at near diffusion-limited rates. $^{1}$

$$
\begin{gathered}
\mathrm{H}_{2} \mathrm{O}_{2}+\mathrm{Fe}(\mathrm{II}) \rightarrow \mathrm{HO}^{\bullet}+\mathrm{OH}^{-}+\mathrm{Fe}(\mathrm{III}) \\
\mathrm{Fe}(\mathrm{III})+\mathrm{H}_{2} \mathrm{O}_{2} \rightarrow \mathrm{Fe}(\mathrm{II})+\mathrm{H}^{+}+\mathrm{HO}_{2}^{\cdot} \\
\mathrm{Fe}(\mathrm{III})+\mathrm{HO}_{2}^{\cdot} \rightarrow \mathrm{Fe}(\mathrm{II})+\mathrm{H}^{+}+\mathrm{O}_{2} \\
\mathrm{Fe}(\mathrm{II})+\mathrm{HO}^{\cdot} \rightarrow \mathrm{Fe}(\mathrm{III})+\mathrm{OH}^{-} \\
\mathrm{HO}^{\bullet}+\mathrm{H}_{2} \mathrm{O}_{2} \rightarrow \mathrm{H}_{2} \mathrm{O}+\mathrm{HO}_{2}^{\cdot}
\end{gathered}
$$

${ }^{a}$ College of Environment and Resources, Jilin University, Changchun 130021, China. E-mail: qincyu@jlu.edu.cn; Tel: +8643188502608

${ }^{b}$ Key Laboratory of Groundwater Resources and Environment, Ministry of Education, Jilin University, Changchun 130021, China

${ }^{c}$ Shenyang Academy of Environmental Sciences, Shenyang 110167, China

$$
\begin{gathered}
\mathrm{Fe}(\mathrm{II})+\mathrm{HO}_{2}^{\cdot} \rightarrow \mathrm{HOO}^{-}+\mathrm{Fe}(\mathrm{III}) \\
\mathrm{HO}^{\bullet}+\mathrm{HO}^{\cdot} \rightarrow \mathrm{H}_{2} \mathrm{O}_{2} \\
\mathrm{HO}^{\bullet}+\text { organics } \rightarrow \text { products }+\mathrm{CO}_{2}+\mathrm{H}_{2} \mathrm{O}
\end{gathered}
$$

However, the conventional Fenton process, which is used primarily for treating waters and wastewaters, is not feasible for in situ soil or groundwater remediation. This is because the conventional Fenton's reaction is usually conducted by gradually adding dilute $\mathrm{H}_{2} \mathrm{O}_{2}$ to a solution of excess $\mathrm{Fe}(\mathrm{II})$ in conditions where the optimal $\mathrm{pH}$ is below 3. Fenton's reagent is usually modified for in situ chemical oxidation (ISCO) using a one-time addition of higher concentration of $\mathrm{H}_{2} \mathrm{O}_{2}$ and varying the type of catalyst (i.e. $\mathrm{Fe}(\mathrm{II}), \mathrm{Fe}(\mathrm{III})$, iron chelates, or iron minerals). ${ }^{7,8}$ A high concentration of liquid $\mathrm{H}_{2} \mathrm{O}_{2}$ is typically injected in the subsurface for the supply of $\mathrm{H}_{2} \mathrm{O}_{2}$ in the modified Fenton system (MF, or Fenton-like system). However, the $\mathrm{H}_{2} \mathrm{O}_{2}$ utilization efficiency is very low because of the instability of $\mathrm{H}_{2} \mathrm{O}_{2}$ in the subsurface. ${ }^{9}$ It has been reported that liquid $\mathrm{H}_{2} \mathrm{O}_{2}$ can only persist from a few minutes to several hours after injected into the subsurface. Disproportionation (reaction (9)) constitutes the major loss of $\mathrm{H}_{2} \mathrm{O}_{2}$ at neutral $\mathrm{pH} .^{\mathbf{1 0 , 1 1}}$ It consumes $\mathrm{H}_{2} \mathrm{O}_{2}$ without producing $\mathrm{HO}^{\circ}$ and releases $\mathrm{O}_{2}$ gas, which clogs pores around the injection wells and promotes contaminant volatilization. ${ }^{\mathbf{1 2 , 1 3}}$ Therefore, means for slow and controlled release of the $\mathrm{H}_{2} \mathrm{O}_{2}$ into the subsurface are highly desirable. 


$$
2 \mathrm{H}_{2} \mathrm{O}_{2} \rightarrow \mathrm{H}_{2} \mathrm{O}+\mathrm{O}_{2}
$$

By far, one of the most useful solid forms of peroxide for environmental applications is calcium peroxide $\left(\mathrm{CaO}_{2}\right){ }^{\mathbf{1 4 , 1 5}}$ Previously, $\mathrm{CaO}_{2}$ was mostly used as an oxygen release compound (ORC), which could slowly decompose to release oxygen when in contact with water (reaction (10)). ${ }^{16-18}$ Recent studies showed that $\mathrm{CaO}_{2}$ can be a more effective source of $\mathrm{H}_{2} \mathrm{O}_{2}$ than liquid $\mathrm{H}_{2} \mathrm{O}_{2}$ in MF-ISCO. ${ }^{19,20}$ In fact, $\mathrm{CaO}_{2}$ can dissolve in water to form $\mathrm{H}_{2} \mathrm{O}_{2}$ via eqn (11) at a large pH range, liberating a maximum of $0.47 \mathrm{~g} \mathrm{H}_{2} \mathrm{O}_{2}$ per $\mathrm{g} \mathrm{CaO}_{2}{ }^{21}$ According to the available literature, the yield of $\mathrm{H}_{2} \mathrm{O}_{2}$ from $\mathrm{CaO}_{2}$ decreased, while production of $\mathrm{O}_{2}$ was elevated with the increase of $\mathrm{pH}$ and temperature. ${ }^{19,22}$ And about $70-80 \%$ of $\mathrm{CaO}_{2}$ was transformed to $\mathrm{H}_{2} \mathrm{O}_{2}$ at moderate $\mathrm{pH}$ and temperature. Moreover, $\mathrm{H}_{2} \mathrm{O}_{2}$ released from $\mathrm{CaO}_{2}$ is autoregulated by the rate of $\mathrm{CaO}_{2}$ dissolution, reducing disproportionation of $\mathrm{H}_{2} \mathrm{O}_{2}$ to $\mathrm{O}_{2}$ since not all the $\mathrm{H}_{2} \mathrm{O}_{2}$ is available at once as it is with liquid $\mathrm{H}_{2} \mathrm{O}_{2}$.

$$
\begin{aligned}
& \mathrm{CaO}_{2}+\mathrm{H}_{2} \mathrm{O} \rightarrow \mathrm{Ca}(\mathrm{OH})_{2} \downarrow+1 / 2 \mathrm{O}_{2} \uparrow \\
& \mathrm{CaO}_{2}+2 \mathrm{H}_{2} \mathrm{O} \rightarrow \mathrm{Ca}(\mathrm{OH})_{2} \downarrow+\mathrm{H}_{2} \mathrm{O}_{2}
\end{aligned}
$$

The excellent properties of $\mathrm{CaO}_{2}$ to release $\mathrm{H}_{2} \mathrm{O}_{2}$ at a controlled rate attracted more and more researchers to apply $\mathrm{CaO}_{2}$ in MF-ISCO. ${ }^{23,24}$ Ndjou'ou and Cassidy ${ }^{25}$ applied a commercially available $\mathrm{CaO}_{2}$-based oxidant to treat soils contaminated with total petroleum hydrocarbons (TPH) and found that $\mathrm{CaO}_{2}$ removed $96 \%$ of TPH. Bogan et al. ${ }^{20}$ reported that $\mathrm{CaO}_{2}$ performed better than liquid $\mathrm{H}_{2} \mathrm{O}_{2}$ for removing polycyclic aromatic hydrocarbons (PAHs) from soil. Xiang Zhang et al. ${ }^{26}$ used $\mathrm{CaO}_{2}$ activated with ferrous ions to treat trichloroethylene (TCE) with 100\% removal efficiency. Northup and Cassidy ${ }^{19}$ investigated $\mathrm{CaO}_{2}$ dissolution to yield $\mathrm{H}_{2} \mathrm{O}_{2}$ at various $\mathrm{pH}$ conditions and the degradation performance of perchlorethylene (PCE) in the modified Fenton system.

Although the preliminary experimental results look promising, the relationship between 2,4-DCP removal efficiency and the main influencing factors in a $\mathrm{CaO}_{2}$-based $\mathrm{MF}$ system, particularly $\mathrm{CaO}_{2}$ dosage, chelate-Fe(II) content, and solution $\mathrm{pH}$, need to be further studied. In addition, the mechanisms of $\mathrm{CaO}_{2}$-based $\mathrm{MF}$ oxidation and the degradation route of chlorinated aromatic hydrocarbons are still not thoroughly elucidated. In this research, 2,4-dichlorophenol (2,4-DCP) was used as the representative target contaminant of chlorinated aromatic hydrocarbons. The aim of this experiment is first to explore a practical system, which can degrade 2,4-DCP with high removal efficiency, and find out the effect of main experimental parameters on 2,4-DCP removal. Second, molecular probe tests and scavenger tests were conducted to identify the reactive oxygen species responsible for 2,4-DCP degradation. Third, the mineralization of 2,4-DCP was monitored, the main intermediate products were analyzed and the 2,4-DCP degradation pathway was proposed.

\section{Materials and methods}

\subsection{Materials}

Analytical grade calcium peroxide $\left(75 \% \mathrm{CaO}_{2}, 25 \% \mathrm{Ca}(\mathrm{OH})_{2}\right)$ and 2,4-dichlorophenol (2,4-DCP 99.0\%) were purchased from Aladdin Reagent Co. Ltd. (Shanghai, China). Chromatographic grade methyl alcohol $\left(\mathrm{CH}_{3} \mathrm{OH}, 99.9 \%\right)$ was purchased from TEDIA High Purity Solvent Co. Ltd. (Fairfield, America). Acetonitrile $\left(\mathrm{C}_{2} \mathrm{H}_{3} \mathrm{~N}, 99.9 \%\right)$ was purchased from Thermo Fisher Scientific Co. Ltd. (Shanghai, China). Carbon tetrachloride (CT, 99.5\%) was purchased from Tianjin Aoran Chemical Research Institute (Tianjin, China). Monosodium phosphate dihydrate $\left(\mathrm{NaH}_{2} \mathrm{PO}_{4} \cdot 2 \mathrm{H}_{2} \mathrm{O}, 99.0 \%\right)$ and disodium phosphate dodecahydrate $\left(\mathrm{Na}_{2} \mathrm{HPO}_{4} \cdot 12 \mathrm{H}_{2} \mathrm{O}, 99 \%\right)$, anhydrous disodium ethylenediaminetetraacetate $\left(\mathrm{C}_{10} \mathrm{H}_{14} \mathrm{O}_{8} \mathrm{~N}_{2} \mathrm{Na}_{2}\right.$, EDTA, 99\%), sodium formate $\left(\mathrm{NaCHO}_{2}, 99.5 \%\right)$, sodium acetate $\left(\mathrm{NaC}_{2} \mathrm{H}_{3} \mathrm{O}_{2}, 99.0 \%\right)$, acetic acid $\left(\mathrm{C}_{2} \mathrm{H}_{4} \mathrm{O}_{3}, 99.5 \%\right)$, sodium oxalate $\left(\mathrm{Na}_{2} \mathrm{C}_{2} \mathrm{O}_{4}, 99.8 \%\right)$, ammonium acetate $\left(\mathrm{C}_{2} \mathrm{H}_{7} \mathrm{O}_{2} \mathrm{~N}, 99 \%\right)$, tert-butyl alcohol $\left(\left(\mathrm{CH}_{3}\right)_{3} \mathrm{OH}\right.$, TBA, 98.0\%), hydrogen peroxide $\left(\mathrm{H}_{2} \mathrm{O}_{2}, 30 \%\right)$ and ferrous sulfate heptahydrate $\left(\mathrm{FeSO}_{4} \cdot 7 \mathrm{H}_{2} \mathrm{O}, 99.0 \%\right)$ were purchased from the Sinopharm Chemical Reagent Co. Ltd. (Beijing, China). Ammonium molybdate $\left(\left(\left(\mathrm{NH}_{4}\right)_{6} \mathrm{Mo}_{7} \mathrm{O}_{24}\right)\right.$, 99.0\%), trichloromethane $\left(\mathrm{CHCl}_{3}, 99.0 \%\right)$, nitrobenzene ( $\mathrm{NB}$, 99.0\%), sodium hydroxide ( $\mathrm{NaOH}, 96 \%)$ and methanol $\left(\mathrm{CH}_{3} \mathrm{OH}, 99.9 \%\right)$ were purchased from Beijing Chemical Works (Beijing, China). Ultrapure water from a Milli-Q water process (Classic DI, ELGA, Marlow, UK) was used for preparing aqueous solutions.

\subsection{Preparation}

The buffer solutions used in this study were prepared with $\mathrm{NaH}_{2} \mathrm{PO}_{4} \cdot 2 \mathrm{H}_{2} \mathrm{O}$ and $\mathrm{Na}_{2} \mathrm{HPO}_{4} \cdot 12 \mathrm{H}_{2} \mathrm{O}$ in de-ionized water. Buffer solutions with three different $\mathrm{pH}$ values (6.0, 7.0 and 8.0) were chosen to evaluate the effect of $\mathrm{pH}$ on the degradation performance. The buffer strength of the solutions was $0.05 \mathrm{~mol}$ $\mathrm{L}^{-1}$. Preliminary testing verified that each buffer solution was able to maintain the desired $\mathrm{pH}$ with the dose of $\mathrm{CaO}_{2}$ and other reagents used. A stock solution of 2,4-DCP was prepared by allowing the pure non-aqueous phase liquid 2,4-DCP to equilibrate with buffer solutions of desired $\mathrm{pH}$ value under gentle stirring and then diluted to the desired concentration. In the studies, each reactor also received EDTA chelated Fe(II) to catalyze the MF reaction. The initial concentration of 2,4-DCP was kept at $100 \mathrm{mg} \mathrm{L}^{-1}(0.61 \mathrm{mM})$. In all experiments except for the effect of $\mathrm{CaO}_{2}$ dosage and the amount of EDTA-Fe(II) on the degradation performance, the initial molar ratio of $\mathrm{CaO}_{2} / \mathrm{EDTA}-$ $\mathrm{Fe}(\mathrm{II}) / 2,4-\mathrm{DCP}$ was set as 16/4/1.

\subsection{Procedure}

All experiments were conducted in a $250 \mathrm{~mL}$ jacketed cylindrical glass reactor with a constant temperature of $22{ }^{\circ} \mathrm{C} \pm 0.5{ }^{\circ} \mathrm{C}$ using a thermostat circulating water bath. A magnetic stirrer was used to ensure the uniformity of contaminants. After the chemicals participating in the reaction, except for $\mathrm{CaO}_{2}$ (for instance, 2,4-DCP, EDTA chelated ferrite, etc.), were dissolved in the reactor and the reaction was started by adding the desired 
$\mathrm{CaO}_{2}$ dosage. Samples were withdrawn at desired time intervals and immediately quenched with methyl alcohol before the analysis of 2,4-DCP. In order to identify the reactive oxygen species generated during the reaction, probe tests were conducted in accordance with the 2,4-DCP degradation procedure and 2,4-DCP was replaced by $\mathrm{NB}\left(\mathrm{HO}^{*}\right.$ probe) ${ }^{27,28}$ or $\mathrm{CT}\left(\mathrm{O}_{2}{ }^{-}\right.$ probe). ${ }^{29,30}$ Furthermore, to evaluate the contribution of the reactive oxygen species to 2,4-DCP degradation, TBA ( $\mathrm{HO}^{*}$ scavenger $)^{28}$ and $\mathrm{CHCl}_{3}\left(\mathrm{O}_{2}{ }^{-}\right.$scavenger $),{ }^{29}$ as radical scavengers, had been applied in the experiments to observe 2,4-DCP degradation changes. Phosphate buffer solutions at three $\mathrm{pH}$ values $(6.0,7.0$ and 8.0) were chosen to observe the effect of $\mathrm{pH}$ on the degradation performance and in other experiments, the $\mathrm{pH}$ of solution was maintained at 7.0. All experiments were conducted in duplicate and the mean values were reported. The standard deviations in all experiments were in the range of 0.012-0.050.

\subsection{Analyses}

The concentrations of 2,4-DCP and NB were measured by means of an Agilent 1100 high performance liquid chromatograph (HPLC) with a C18 reversed-phase column ( $5 \mu \mathrm{m}, 4.6 \mathrm{~mm}$ $\times 150 \mathrm{~mm}$ ) and a diode array detector (DAD). To determinate the concentration of 2,4-DCP, the mobile phase was methanol/ water $(70: 30, \mathrm{v} / \mathrm{v})$ with a flow rate of $1.0 \mathrm{~mL} \mathrm{~min}^{-1}$. The UV detector was set at $225 \mathrm{~nm}$. To measure aqueous samples containing $\mathrm{NB}$, the mobile phase was acetonitrile/acetate buffer solution $(65: 35, \mathrm{v} / \mathrm{v})$ with a flow rate of $1.0 \mathrm{~mL} \mathrm{~min}{ }^{-1}$. The UV detector was set at $262 \mathrm{~nm}$. The degradation intermediates were identified using a Waters ultra performance liquid chromatography (UPLC) with an Acquity UPLC C18 column (1.7 $\mu \mathrm{m}, 2.1 \times 100 \mathrm{~mm})$ and Quattro Premier ${ }^{\mathrm{TM}} \mathrm{XE}$ mass spectrometer. The mobile phase was methanol/water $(70: 30, \mathrm{v} / \mathrm{v})$ with a flow rate of $0.25 \mathrm{~mL} \mathrm{~min}^{-1}$. The desolvation gas was $\mathrm{N}_{2}$ and the gas temperature was $400{ }^{\circ} \mathrm{C}$. The ion source temperature was set at $110{ }^{\circ} \mathrm{C}$. CT in the solution was first extracted with hexane $(1 \mathrm{~mL})$ for $3 \mathrm{~min}$ using a vortex stirrer and kept standing for $5 \mathrm{~min}$ for separation. Extracts containing CT were then measured by means of an Agilent 6890A gas chromatograph with an autosampler (Agilent 7693), a DB-VRX column $(1.4 \mu \mathrm{m}, 0.25 \mathrm{~mm} \times 60 \mathrm{~m})$ and an electron capture detector (ECD). The temperatures of the injector, column and ECD detector were set at $240{ }^{\circ} \mathrm{C}, 80^{\circ} \mathrm{C}$ and $260{ }^{\circ} \mathrm{C}$, respectively.

Total organic carbon (TOC) was measured by a total organic carbon analyzer (TOC-L, Shimadzu, Japan). The $\mathrm{H}_{2} \mathrm{O}_{2}$ concentration in aqueous phase was determined using a spectrophotometer (Evolution, Thermo, United States) at a wavelength of $340 \mathrm{~nm}$ after the color was developed by ammonium molybdate. The solution $\mathrm{pH}$ was analyzed using a yellow spring instrument (YSI-100, America) pH-meter. To determine the concentration of chloride ions $\left(\mathrm{Cl}^{-}\right)$, carboxylic acids and EDTA, an ion chromatograph (ICS-2100, Dionex, Germany) equipped with a Dionex RFICTM IonPac® AS 19 analytical column $(4 \mathrm{~mm} \times 250 \mathrm{~mm})$ was used throughout the experiment. The eluent was $3.5 \mathrm{mM} \mathrm{KOH}$ with a flow rate of $1.0 \mathrm{~mL} \min ^{-1}$.

\section{Experimental results and discussion}

\subsection{The performance of 2,4-DCP degradation in a Fenton- like system}

The degradation of 2,4-DCP along time under different experimental conditions was evaluated as shown in Fig. 1.

The experiments were carried out with a fixed 2,4-DCP concentration at different $\mathrm{CaO}_{2}\left(\right.$ or $\mathrm{H}_{2} \mathrm{O}_{2}$ )/EDTA-Fe(II)/2,4-DCP molar ratios. The $\mathrm{pH}$ value was maintained at 7.0 with phosphate buffer and the temperature was kept at $22{ }^{\circ} \mathrm{C}$. It was observed that within $450 \mathrm{~min}$ of reaction time, less than $5 \%$ removal of 2,4-DCP was obtained with a molar ratio of 16/0/1. In the $\mathrm{H}_{2} \mathrm{O}_{2}$ /EDTA-Fe(II)/2,4-DCP system, 2,4-DCP was removed completely within only $20 \mathrm{~min}$ and as the degradation reaction progressed, a large amount of micro-bubbles were generated in the solution. It means that a large amount of $\mathrm{H}_{2} \mathrm{O}_{2}$ decomposed to $\mathrm{O}_{2}$ during this violent degradation reaction and this problem would be magnified when $\mathrm{H}_{2} \mathrm{O}_{2}$ is applied to actual site remediation according to previous studies. ${ }^{10,11}$

Remarkable degradation of 2,4-DCP was also achieved in the $\mathrm{CaO}_{2} /$ EDTA-Fe(II) system. However, the degradation rate was relatively moderate compared with that of the conventional $\mathrm{H}_{2} \mathrm{O}_{2}$ /EDTA-Fe(II) system. In the $\mathrm{CaO}_{2} /$ EDTA-Fe(II) system, the removal efficiency of 2,4-DCP reached $83.0 \%$ within 30 minutes, and then the degradation rate (slope of the degradation curves) slowed down gradually. It indicates that remarkable degradation of 2,4-DCP was also achieved in the $\mathrm{CaO}_{2} / \mathrm{EDTA}-\mathrm{Fe}$ (II) system with a relatively moderate degradation rate compared with that of the conventional $\mathrm{H}_{2} \mathrm{O}_{2} / \mathrm{EDTA}-\mathrm{Fe}(\mathrm{II})$ system. According to the literature and our previous studies, ${ }^{19,22} \mathrm{CaO}_{2}$ can slowly release $\mathrm{H}_{2} \mathrm{O}_{2}$ after being dissolved in water. It can thus be reasonably deduced that EDTA-Fe(II) reacted quickly with $\mathrm{H}_{2} \mathrm{O}_{2}$ released by $\mathrm{CaO}_{2}$ and the reaction facilitated the $\mathrm{CaO}_{2}$ dissolution simultaneously, generating a large amount of reactive oxygen species. Along with the generation of $\mathrm{H}_{2} \mathrm{O}_{2}$, $\mathrm{Ca}(\mathrm{OH})_{2}$ can also be formed through reaction (11), but phosphate buffer solution was able to maintain the desired pH. In addition, only a small amount of bubbles, which were considered as $\mathrm{O}_{2}$, were generated in the $\mathrm{CaO}_{2} / \mathrm{EDTA}-\mathrm{Fe}$ (II) system. It is

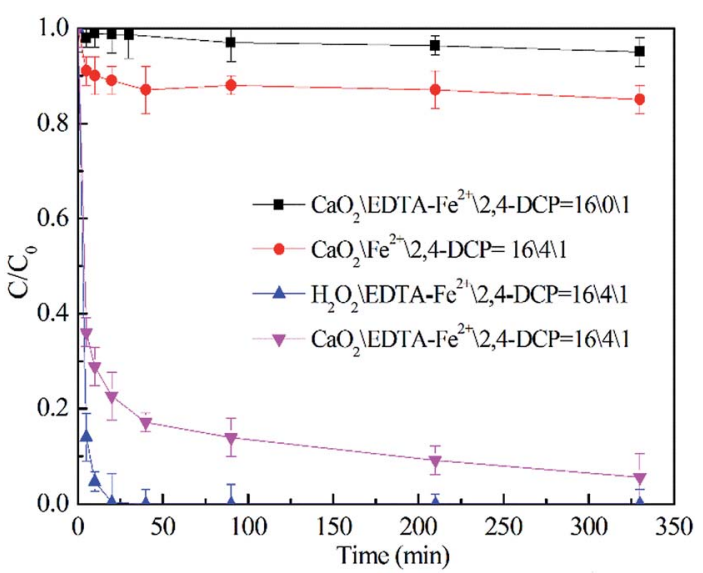

Fig. 1 Degradation of 2,4-DCP by $\mathrm{CaO}_{2}$ or $\mathrm{H}_{2} \mathrm{O}_{2}$ in a modified Fenton system $\left([2,4-D C P]_{0}=0.61 \mathrm{mM}\right)$. 
concluded that $\mathrm{CaO}_{2}$, compared with $\mathrm{H}_{2} \mathrm{O}_{2}$, can dramatically prolong the contaminant removal reaction time by releasing $\mathrm{H}_{2} \mathrm{O}_{2}$ at a controlled rate and enhance the utilization efficiency of peroxide by reducing the $\mathrm{O}_{2}$ yield, which is not responsible for the MF reaction. The abovementioned results demonstrated that it was much more feasible to use $\mathrm{CaO}_{2}$ as a long-term source of $\mathrm{H}_{2} \mathrm{O}_{2}$ to promote MF-ISCO.

To investigate the activity of EDTA-Fe(II) in the degradation of 2,4-DCP, a control experiment was conducted with the molar ratio of $\mathrm{CaO}_{2} / \mathrm{Fe}(\mathrm{II}) / 2,4-\mathrm{DCP}$, consistent with that of other systems. It can be observed that only $13 \%$ of 2,4 -DCP was removed without the addition of EDTA, whereas 95\% of 2,4-DCP was removed in the system of $\mathrm{CaO}_{2} /$ EDTA-Fe(II)/2,4-DCP. Total iron testing (not shown) showed that only little soluble iron remained in the system at the end of experiments. By contrast, about $70 \%$ of initial iron was detected in the $\mathrm{CaO}_{2} / \mathrm{EDTA}-\mathrm{Fe}(\mathrm{II}) /$ 2,4-DCP system. The low degrading efficiency in the $\mathrm{CaO}_{2} / \mathrm{Fe}(\mathrm{II}) /$ 2,4-DCP system is probably ascribed to the sharp decrease of the concentration of soluble iron. Two reasons can account for the diminution of $\mathrm{Fe}$ (II) catalytic activity. On one hand, phosphate used to buffer $\mathrm{pH}$ can combine most of the $\mathrm{Fe}(\mathrm{II})$ in solution to form sediment as soon as $\mathrm{Fe}(\mathrm{II})$ is added into the solution. On the other hand, the other part of $\mathrm{Fe}(\mathrm{II})$ involved in Fenton degradation was oxidized to $\mathrm{Fe}(\mathrm{III})$ immediately by $\mathrm{HO}^{*}$ and then converted to a precipitate of $\mathrm{Fe}(\mathrm{OH})_{3}$ completely within the first $5 \mathrm{~min}$. Once iron was converted to a precipitate, it could no longer participate in the radical propagation cycle. It can be concluded that chelation of EDTA can effectively maintain the catalytic activity of $\mathrm{Fe}(\mathrm{II})$ in Fenton chemistry based on $\mathrm{CaO}_{2}$ at moderate $\mathrm{pH}$.

\subsection{Decay of EDTA-Fe(II) in a Fenton-like system}

To better understand the role of EDTA chelated Fe(II) in the 2,4DCP degradation process, the decay mechanisms of EDTA and iron ions were also investigated. As observed in Fig. 2, similar to the degradation process of 2,4-DCP, the concentration of EDTA shows a prominent decrease during the reaction time. This is because $\mathrm{HO}^{\circ}$ generated in the MF system have a great oxidizing

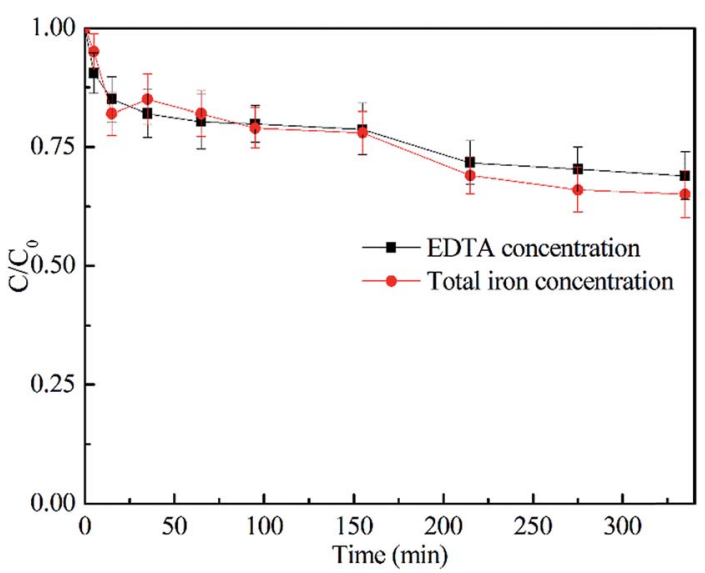

Fig. 2 Decay of EDTA-Fe(॥) in the degradation process of 2,4-DCP. (The molar ratio of $\mathrm{CaO}_{2} /$ EDTA-Fe(॥)/2,4-DCP was kept at 16/4/1.) power and can degrade both 2,4-DCP and EDTA indiscriminately to form carboxylic acids of small molecules or $\mathrm{CO}_{2}$. Previous studies also showed the degradation of EDTA in the MF system..$^{31,32}$ In addition to this, the identification results of deposits in the bottom of the reactor showed the presence of EDTA, which indicates that a small amount of EDTA initially dissolved in the solution precipitated out during the reaction time.

It can also be observed that the variation of iron ion concentration was in accordance with EDTA, which is because the dissociated iron ions with the decay of the chelating agent will soon react with $\mathrm{OH}^{-}$to form sediment and precipitate out from the solution. Although concentrations of both EDTA and iron ions were reduced by $20-30 \%$ at the end of the experiments, the concentration left in the MF system was still enough for catalytic reaction during the following experiment.

\subsection{Effects of reaction parameters on 2,4-DCP removal performance}

3.3.1 Effect of $\mathrm{CaO}_{2}$ dosage. The oxidation of 2,4-DCP at $\mathrm{pH}$ 7.0 and a temperature of $22{ }^{\circ} \mathrm{C}$ with different $\mathrm{CaO}_{2}$ dosages was investigated and shown in Fig. 3. It can be seen from the figure that the removal efficiency of 2,4-DCP within 240 min was rapidly increased from $47.0 \%$ to $95.7 \%$ as the molar ratio of $\mathrm{CaO}_{2}$ to 2,4-DCP increased from $4 / 1$ to $16 / 1$. However, with the molar ratio further increasing to $32 / 1$, the degradation removal was decreased to $92.4 \%$. This is because an excess of $\mathrm{CaO}_{2}$ can release an overly high concentration of $\mathrm{H}_{2} \mathrm{O}_{2}$, which was reported to scavenge $\mathrm{HO}^{*}$ as expressed by reaction (5).

Therefore, the initial molar ratio of $\mathrm{CaO}_{2} / 2,4-\mathrm{DCP}$ was chosen as $16 / 1\left(\left[\mathrm{CaO}_{2}\right]_{0}=10 \mathrm{mM}\right)$ for the investigation discussed below.

3.3.2 Effect of EDTA-Fe(II) concentration. Fig. 4 illustrates the effect of EDTA-Fe(II) concentration on 2,4-DCP removal efficiency at $\mathrm{pH} 7.0$ and a temperature of $22{ }^{\circ} \mathrm{C}$ with an initial $\mathrm{CaO}_{2} / 2,4-\mathrm{DCP}$ molar ratio of $16 / 1$. It can be seen that the removal efficiencies of 2,4-DCP at the molar ratios of $\mathrm{CaO}_{2} /$ EDTA-Fe(II)/2,4-DCP varying from $16 / 1 / 1$ to $16 / 8 / 1$ were similar

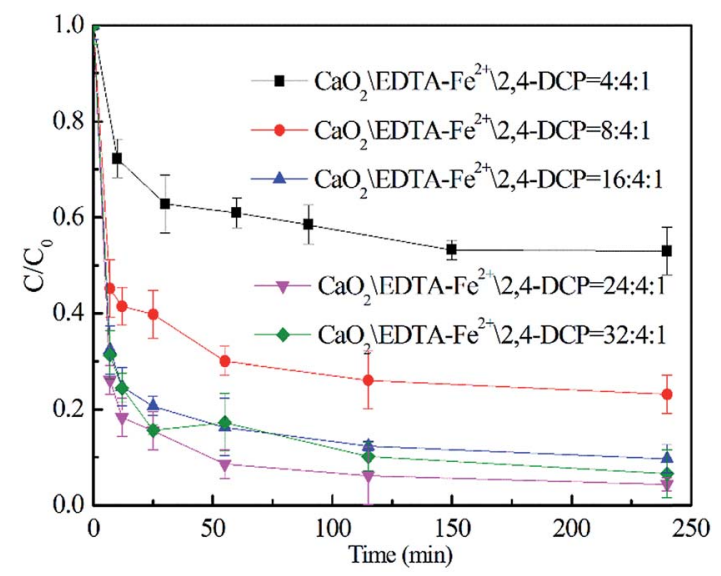

Fig. 3 Effect of $\mathrm{CaO}_{2}$ dosage on 2,4-DCP degradation $\left([2,4-\mathrm{DCP}]_{0}=\right.$ $0.61 \mathrm{mM}$ and the initial concentration of EDTA-Fe(॥) was $2.45 \mathrm{mM}$ ). 


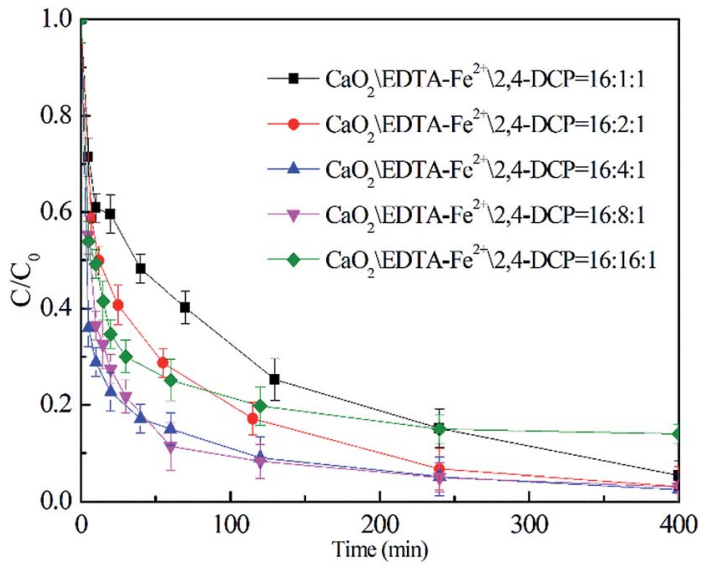

Fig. 4 Effect of EDTA-Fe(॥) addition on 2,4-DCP degradation ([2,4$\left.\mathrm{DCP}]_{0}=0.61 \mathrm{mM}\right)$.

and were all over $95.0 \%$ within $400 \mathrm{~min}$ of reaction time. Nevertheless, the curve slopes representing the degradation rate varied widely with the increase of EDTA-Fe(II) concentration. As observed in the figure, the removal efficiency within $60 \mathrm{~min}$ of reaction time was $57.4 \%$ with the molar ratio kept at $16 / 1 / 1$, whereas it increased to $88.6 \%$ with the molar ratio of EDTA$\mathrm{Fe}(\mathrm{II}) / 2,4$-DCP enhanced to $16 / 8 / 1$. It suggests that the degradation rate of 2,4-DCP was elevated with the molar ratio increased from $16 / 1 / 1$ to $16 / 8 / 1$, though the degradation performances for 2,4-DCP were similar. This can be explained by iron consumption and a regeneration cycle composed of reactions (1) and (2). The rate constant for reaction (1) was tested by former researchers as $63 \mathrm{M}^{-1} \mathrm{~s}^{-1}$, whereas that for reaction (2) was only $0.01 \mathrm{M}^{-1} \mathrm{~s}^{-1} .^{29}$ This means that $\mathrm{Fe}(\mathrm{II})$ ions were consumed faster than they were produced. Accordingly, increasing the $\mathrm{Fe}$ (II) concentration accelerated the degradation process by promoting the decomposition of $\mathrm{H}_{2} \mathrm{O}_{2}$ to produce more $\mathrm{HO}^{\circ}$ at a time and reducing the regeneration cycle numbers. However, when the molar ratio was further increased from $16 / 8 / 1$ to $16 / 16 / 1$, both the degradation performance and the degradation rate decreased dramatically. This is ascribed to the scavenging of $\mathrm{HO}^{\circ}$ or other radicals by present iron species through undesirable reactions (3), (4) and (6). ${ }^{33,34}$

3.3.3 Effect of $\mathbf{p H}$. The effect of $\mathrm{pH}$ on 2,4-DCP degradation was investigated in the $\mathrm{pH}$ range from 5.0 to 8.0 maintained by phosphate buffer solution. It should be noted that solution $\mathrm{pH}$ variation before and after reaction was less than 0.2. As seen from Fig. 5, within $300 \mathrm{~min}$ of reaction time, the removal efficiency decreased from $99.9 \%$ to $77.2 \%$ with the increase of $\mathrm{pH}$ from 5.0 to 8.0. The decreased oxidation efficiency at higher $\mathrm{pH}$ values was attributed to the lower oxidation potential of hydroxyl radicals and the undesirable decomposition of $\mathrm{CaO}_{2}$ to form $\mathrm{O}_{2}$ at higher $\mathrm{pH}$ (eqn (10)). In the degradation process without addition of buffer solution, the concentration of contaminant diminished quickly within $3 \mathrm{~min}$ and then tended to keep a constant value with the final removal efficiency of $51.2 \%$. The reaction ceased probably because $\mathrm{CaO}_{2}$ can react with water to form $\mathrm{Ca}(\mathrm{OH})_{2}$ (eqn (11)), which caused a dramatic increase in $\mathrm{pH}$. Without the addition of buffer reagents, the

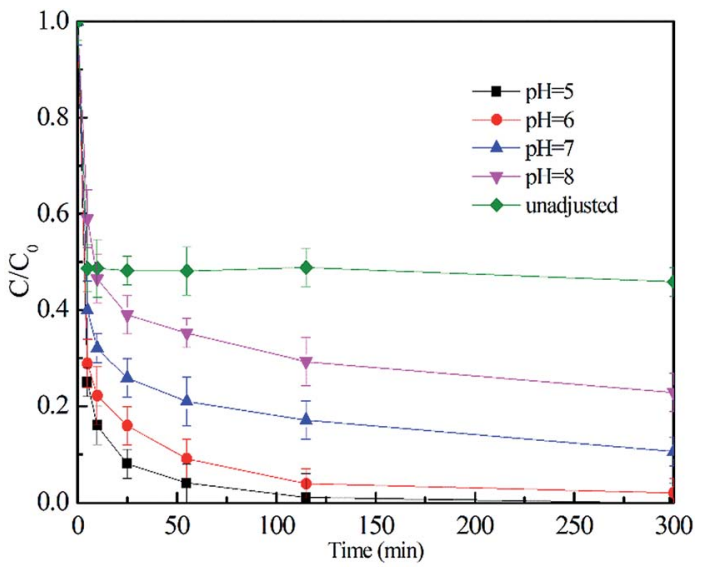

Fig. 5 Effect of $\mathrm{pH}$ on 2,4-DCP degradation performance (molar ratio of $\mathrm{CaO}_{2} / \mathrm{EDTA}-\mathrm{Fe}(॥) / 2,4-\mathrm{DCP}$ in the system was kept at 16/4/1, [2,4$D C P]_{0}=0.61 \mathrm{mM}$ ).

solution $\mathrm{pH}$ rises quickly to more than 11.0, at which point $\mathrm{CaO}_{2}$ is difficult to dissolve to form $\mathrm{H}_{2} \mathrm{O}_{2}$. A pH of 7 was chosen for the following study.

3.3.4 2,4-DCP degradation kinetics. It is known that a modified Fenton reaction is a pseudo-first-order reaction with respect to the concentration of the contaminant. ${ }^{35-38}$ However, the 2,4-DCP degradation in the MF system based on $\mathrm{CaO}_{2}$, particularly with the addition of EDTA, showed a very complex behavior; the 2,4-DCP concentration first decreased rapidly, followed by a much slower degradation process (shown in Fig. 1). This led to a situation where the 2,4-DCP degradation could be fitted by neither zero-, first-, nor second-order kinetics. In fact, the degradation process was controlled by the release of $\mathrm{H}_{2} \mathrm{O}_{2}$ from $\mathrm{CaO}_{2}$ decomposition to a large extent and in our previous study we had concluded that the $\mathrm{H}_{2} \mathrm{O}_{2}$ releasing process from $\mathrm{CaO}_{2}$ decomposition followed a pseudo-zero-order kinetics pattern. ${ }^{22}$

Then, we conducted a series of experiments with the addition of an equivalent amount of $\mathrm{CaO}_{2}$ and with no addition of 2,4-DCP to water to find out the relationship between the 2,4DCP degradation process and release of $\mathrm{H}_{2} \mathrm{O}_{2}$ from $\mathrm{CaO}_{2}$ decomposition. Fig. 6 shows the $\mathrm{H}_{2} \mathrm{O}_{2}$ releasing process from $\mathrm{CaO}_{2}$ dissolution (see the red line) and the 2,4-DCP degradation performance (see the black line) by an equivalent amount of $\mathrm{CaO}_{2}$. In Fig. 6, $C_{\mathrm{A}} / C_{\mathrm{A} 0}$ on the left vertical axis represents the relative concentration of $2,4-\mathrm{DCP}$, whereas $C_{\mathrm{B}} / C_{\mathrm{Bmax}}$ on the right is the $\mathrm{H}_{2} \mathrm{O}_{2}$ productivity. The results show that without the addition of 2,4-DCP, $\mathrm{H}_{2} \mathrm{O}_{2}$ can be generated gradually from $\mathrm{CaO}_{2}$ dissolution at a certain rate, regardless of the decreasing $\mathrm{CaO}_{2}$ content in solution (see the solid red line). It needs to be noted that a significant amount of $\mathrm{H}_{2} \mathrm{O}_{2}$ was produced instantaneously once $\mathrm{CaO}_{2}$ was added to the solution to initiate the experiment. Therefore, the $\mathrm{H}_{2} \mathrm{O}_{2}$ releasing process from $\mathrm{CaO}_{2}$ dissolution can be fitted approximately by a line disjointed to the zero point. Consequently, in the initial stage of the degradation reaction, the $\mathrm{H}_{2} \mathrm{O}_{2}$ concentration was relatively high to react with EDTA-Fe(II) and form $\mathrm{HO}^{\circ}$, which can degrade 2,4DCP at a higher rate. With the reaction going on, $\mathrm{H}_{2} \mathrm{O}_{2}$, which 


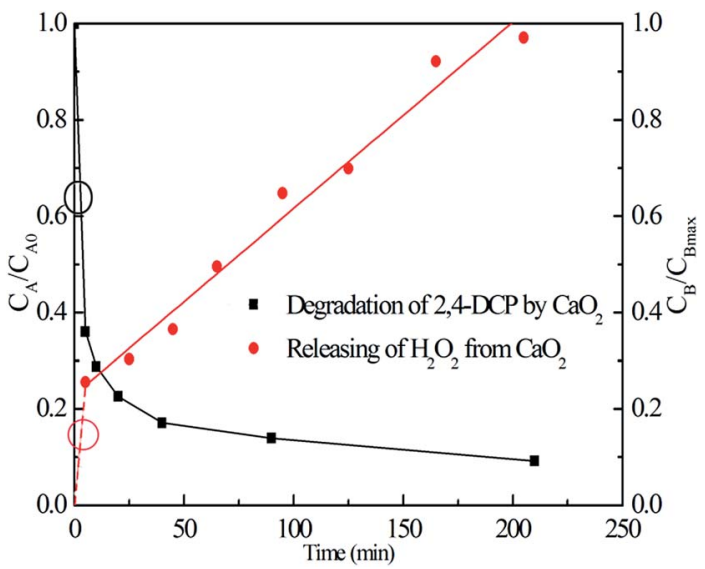

Fig. 6 Releasing curve of $\mathrm{H}_{2} \mathrm{O}_{2}$ from $\mathrm{CaO}_{2}$ decomposition and the degradation curve of 2,4-DCP by a comparable amount of $\mathrm{CaO}_{2}$ (the molar ratio of $\mathrm{CaO}_{2} /$ EDTA-Fe(॥)/2,4-DCP in the system was kept at $\left.16 / 4 / 1,[2,4-D C P]_{0}=0.61 \mathrm{mM}\right)$.

was released from $\mathrm{CaO}_{2}$ at a certain slow rate, was relatively "insufficient" for the following degradation process. Accordingly, the 2,4-DCP degradation in the $\mathrm{Ca}_{2} \mathrm{O}_{2} /$ EDTA-Fe(II) system showed a moderate reaction rate because of the dissolution process of $\mathrm{CaO}_{2}$ particles.

\subsection{Identification of predominant reactive oxygen species}

3.4.1 Free radical probe compound tests. To verify the generation of reactive oxygen species, NB and CT were used as the probe compounds on the basis of their reactivity with each type of species potentially presented in the system. NB was selected as the oxidant probe to demonstrate the presence of $\mathrm{HO}^{*}$ since it has high reactivity with $\mathrm{HO}^{-}\left(k_{\mathrm{HO}}=3.9 \times 10^{9} \mathrm{M}^{-1}\right.$ $\left.\mathrm{s}^{-1}\right){ }^{27}$ Apart from the oxidative species, the system may also have potential in generating reductive species such as $\mathrm{O}_{2}{ }^{-}$. CT, which is a highly oxidized compound, was used for identifying $\mathrm{O}_{2}{ }^{-}$because of its high reactivity with reductants $(k=1.6 \times$ $10^{10} \mathrm{M}^{-1} \mathrm{~s}^{-1}$ ), but extremely low reactivity with hydroxyl radicals $\left(k_{\mathrm{HO}} \cdot<2 \times 10^{6} \mathrm{M}^{-1} \mathrm{~s}^{-1}\right){ }^{29}$

The generation of $\mathrm{HO}^{-}$in a $\mathrm{CaO}_{2}$-based Fenton system, measured by NB loss, is shown in Fig. 7. The NB removal efficiency was above $95 \%$ in $240 \mathrm{~min}$ of reaction time, proving that $\mathrm{HO}^{\circ}$ was generated in the system. The presence of $\mathrm{HO}^{*}$ demonstrated the ability of $\mathrm{CaO}_{2}$ to replace $\mathrm{H}_{2} \mathrm{O}_{2}$ to participate in the modified Fenton system. The removal efficiency of CT can reach $24 \%$ within 240 min of reaction time in the modified Fenton system, indicating the presence of $\mathrm{O}_{2}{ }^{-}$in the system. Previous studies ${ }^{28}$ have shown that $\mathrm{O}_{2}{ }^{-}$is likely a transforming species in the modified Fenton's process and is probably formed in the processes represented by eqn (5) and (12):

$$
\mathrm{HO}_{2}^{\cdot} \leftrightarrow \mathrm{O}_{2}^{-}+\mathrm{H}^{+}
$$

3.4.2 Free radical scavenger tests. In order to identify the major reactive oxygen species for 2,4-DCP removal, free radical scavenger tests with two types of scavengers were conducted.

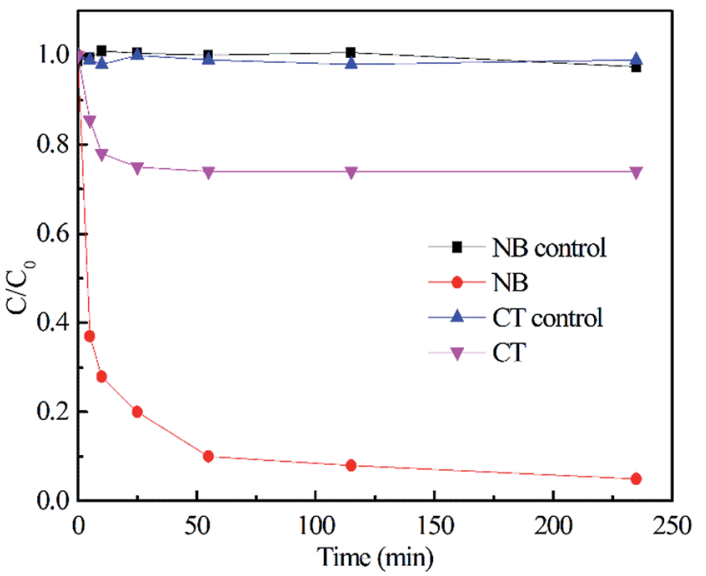

Fig. 7 The degradation of probe compounds in the $\mathrm{CaO}_{2}$ /EDTA-Fe(॥) system $\left([\mathrm{NB}]_{0}=1 \mathrm{mM},[\mathrm{CT}]_{0}=0.05 \mathrm{mM},\left[\mathrm{CaO}_{2}\right]_{0}=10 \mathrm{mM},[\mathrm{Fe}(\Perp)]_{0}=\right.$ $\left.20 \mathrm{mM}, T=22^{\circ} \mathrm{C} \pm 0.5^{\circ} \mathrm{C}\right)$.

Literature indicates that TBA reacts with $\mathrm{HO}^{\circ}$ at high rates $\left(k_{\mathrm{HO}}\right.$. $\left.=5.2 \times 10^{8} \mathrm{M}^{-1} \mathrm{~s}^{-1}\right)$, and chloroform has minimal reactivity with $\mathrm{HO}^{\cdot}\left(k_{\mathrm{HO}}=7 \times 10^{6} \mathrm{M}^{-1} \mathrm{~s}^{-1}\right)$ and high reactivity with $\mathrm{O}_{2}^{-}$ $\left(k_{\mathrm{O}_{2}}{ }^{-}=3 \times 10^{10} \mathrm{M}^{-1} \mathrm{~s}^{-1}\right) \cdot{ }^{29,31}$ Based on these properties, TBA was used to scavenge $\mathrm{HO}^{\circ}$, whereas chloroform was selected as the $\mathrm{O}_{2}{ }^{-}$scavenger. As shown in Fig. 8(a), the 2,4-DCP removal efficiency in $60 \mathrm{~min}$ of reaction time reached $83.8 \%$ in the absence of the scavenger. As TBA was added to the system from $0 \mathrm{mM}$ to $30 \mathrm{mM}$ and $100 \mathrm{mM}$, the 2,4-DCP removal efficiencies within $60 \mathrm{~min}$ decreased to $47.0 \%$ and $18.5 \%$, respectively. The removal efficiency decreased dramatically with scavenging of $\mathrm{HO}^{\circ}$. This demonstrates that $\mathrm{HO}^{\circ}$ is the dominant reactive oxygen species responsible for 2,4 -DCP degradation in the system.

The result of the $\mathrm{O}_{2}{ }^{-}$scavenging test with chloroform is shown in Fig. 8(b). As seen from it, the removal efficiency of 2,4DCP within 200 min of reaction time was decreased from $90.2 \%$ to $84.5 \%$ and $82.3 \%$, respectively, in the presence of chloroform from 0 to $3 \mathrm{mM}, 10 \mathrm{mM}$, and $30 \mathrm{mM}$. It means that the degradation performance of 2,4-DCP shows a minor decrease with the scavenging of some $\mathrm{O}_{2}{ }^{-}$. It can be deduced that $\mathrm{O}_{2}{ }^{-}$was generated in the system, but its role of promoting the degradation of 2,4-DCP is limited. It is potentially because the $\mathrm{O}_{2}{ }^{-}$ was generated in the reaction steps, which were not essential to the degradation. The result agrees well with former studies. ${ }^{\mathbf{3 1}}$

\subsection{Degradation intermediates and reaction mechanism}

As chloride substituents on the benzene ring are responsible for the toxicity of aromatic compounds, the fate of chloride substituents must be given much more concern. As observed from Fig. 9(a), the initial concentration of 2,4-DCP was $77.4 \mathrm{mg}$ $\mathrm{L}^{-1}$ and removal efficiency was $95.7 \%$. The calculated dechlorination degree of 2,4-DCP reached $90 \%$, showing that most of the chlorine on the aromatic ring was released and formed chloride ions. The mineralization degree of 2,4-DCP in this MF system was determined to investigate the oxidation efficiency of 2,4-DCP (as depicted in Fig. 9(a)). The initial concentration of 

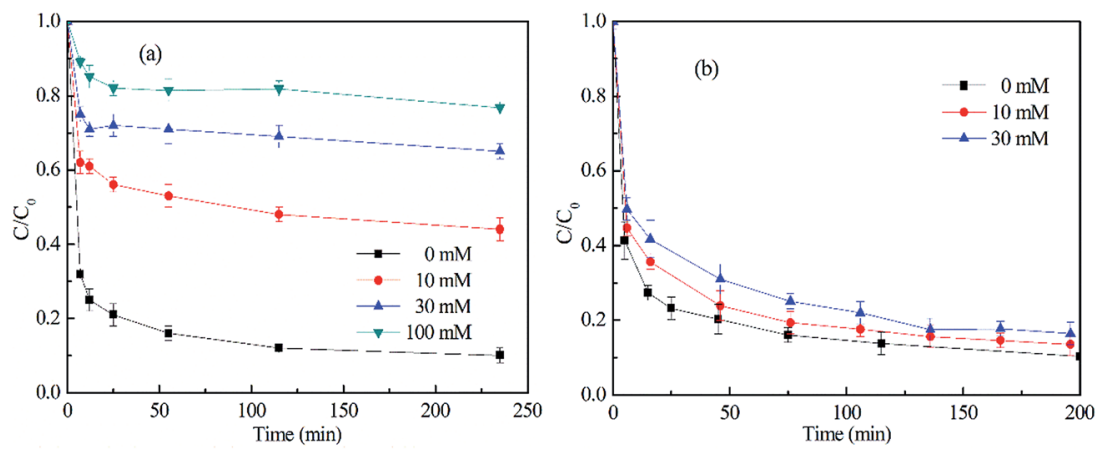

Fig. 8 Effect of radical scavengers on the degradation of 2,4-DCP. The radical scavengers in (a) and (b) were TBA and chloroform, respectively. (The molar ratio of $\mathrm{CaO}_{2} /$ EDTA-Fe(॥)/2,4-DCP was $16 / 4 / 1,[2,4-\mathrm{DCP}]_{0}=0.61 \mathrm{mM}$.)
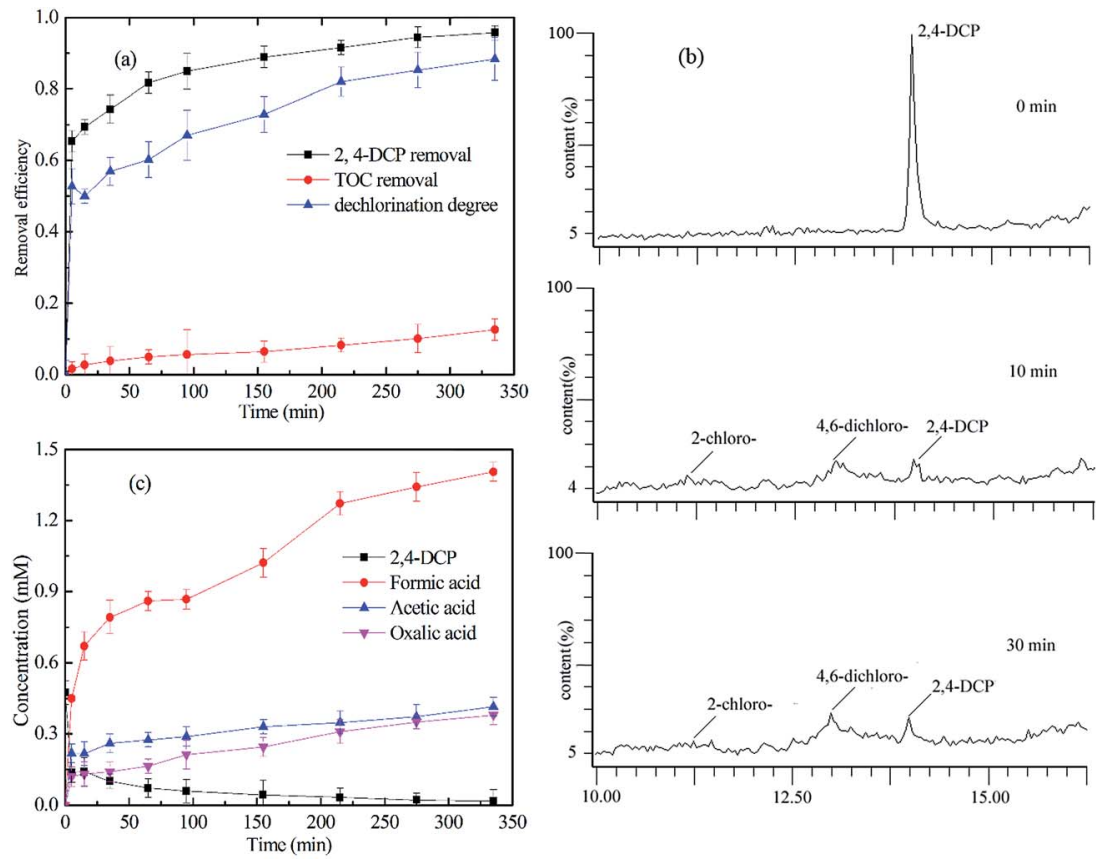

Fig. 9 (a) 2,4-DCP degradation efficiency, TOC removal and dechlorination degree of 2,4-DCP; (b) chromatogram of degradation intermediates detected by UPLC-MS; (c) the concentration of degradation intermediates detected by IC. (The molar ratio of $\mathrm{CaO} 2 / \mathrm{EDTA}-\mathrm{Fe}(॥) / 2,4-\mathrm{DCP}$ was kept at 16/4/1.)

EDTA was $711.2 \mathrm{mg} \mathrm{L}^{-1}$ and the initial concentration of TOC (including 2,4-DCP and EDTA) in the system was measured as $374.9 \mathrm{mg} \mathrm{L}^{-1}$. The final TOC at $300 \mathrm{~min}$ was tested as $327.7 \mathrm{mg}$ $\mathrm{L}^{-1}$. Therefore, the calculated mineralization of 2,4-DCP in the oxidant system is $12.6 \%$. This suggests that some of the intermediates derived from 2,4-DCP decomposition, such as carboxylic acids, remained in the solution.

Through UPLC-MS/MS and IC analyses, the main intermediates were 2-chlorohydroquinone, 4,6-dichlororesorcinol, acetic acid, formic acid and oxalic acid (shown in Fig. 9(b) and (c)). The concentration of 2,4-DCP decreased quickly in the solution during the first $30 \mathrm{~min}$ and then decreased slowly till complete removal within $300 \mathrm{~min}$. 2-Chlorohydroquinone and 6-dichlororesorcinol were generated quickly after the degradation reaction was initiated and began to disappear within $30 \mathrm{~min}$. The acetic acid and formic acid were formed quickly during the first
$30 \mathrm{~min}$ and then were generated slowly during the remaining reaction time. It should be noted that the total concentration of carboxylic acid was relatively high compared to that of the direct products from 2,4-DCP, which is ascribed to the degradation of a small amount of EDTA (shown in Fig. 2). Previous researchers have reported the degradation intermediates of monochlorophenol and phenol, but they were not detected in our system. ${ }^{39,40}$

According to the results and the information reported in the literature, ${ }^{\mathbf{4 1 - 4 4}}$ the degradation pathway was proposed and shown in Fig. 10. The chlorine atom located in the para-position on the aromatic ring of 2,4-DCP was apparently the preferred location for radical attack because of steric effects. Hence, 2,4-DCP was substituted by $\mathrm{HO}^{\circ}$ and degraded to 2-chlorohydroquinone. This 2-chlorohydroquinone was subsequently dehydrogenated to give 2-chloro-1,4-benzoquinone with further attack of $\mathrm{HO}^{\circ}$. Moreover, 


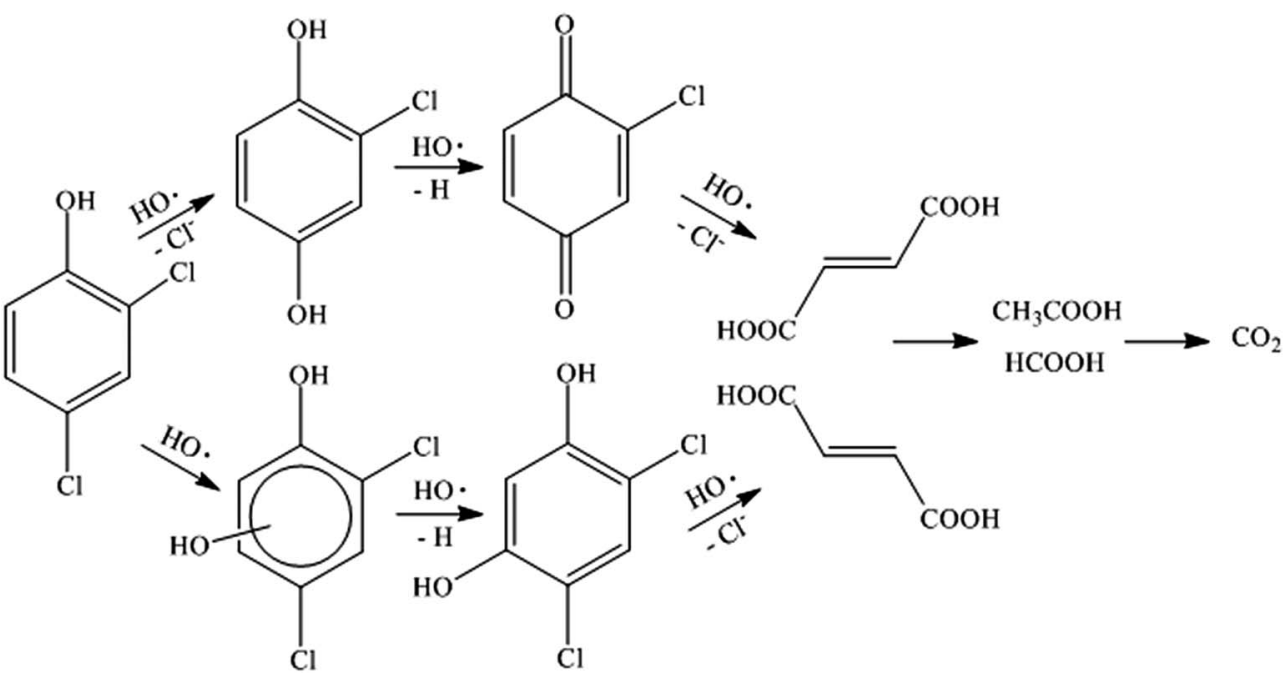

Fig. 10 The suggested pathway for the degradation of 2,4-DCP in the MF system.

the mechanism also allows an electrophilic $\mathrm{HO}^{\circ}$ group to be added onto the aromatic ring of the 2,4-DCP, forming hydroxylation intermediates such as 4,6-dichlororesorcinol. Further oxidation of chlorobenzoquinone and 4,6-dichlororesorcinol leads to dechlorination, followed by ring cleavage and formation of maleic and fumaric acids. These two acids were subsequently oxidized and transformed into acetic acid and formic acid remaining in solution eventually.

\section{Conclusion}

$\mathrm{A} \mathrm{CaO}_{2}$-based modified Fenton system suitable for remediating contaminated groundwater was developed. Since $\mathrm{H}_{2} \mathrm{O}_{2}$ released from $\mathrm{CaO}_{2}$ is auto-regulated by the rate of $\mathrm{CaO}_{2}$ dissolution, this system can not only remove 2,4-DCP from aqueous solution with a moderate reaction rate, but also shows a high utilization efficiency of $\mathrm{H}_{2} \mathrm{O}_{2}$ by inhibiting disproportionation of $\mathrm{H}_{2} \mathrm{O}_{2}$ to form $\mathrm{O}_{2}$. Addition of EDTA can effectively maintain the dissolution of iron at neutral $\mathrm{pH}$, thus increasing the degradation performance. However, some EDTA will be lost due to oxidation or precipitation. A type of complicated kinetics of 2,4-DCP degradation was observed in the $\mathrm{CaO}_{2}$-based modified Fenton system. EDTA-Fe(II) content, $\mathrm{CaO}_{2}$ dosage and $\mathrm{pH}$ value could clearly affect the degradation performance. According to the aromatic intermediates, carboxylic acids and chloride ions determined by UPLC-MS and IC, a possible degradation pathway based on $\mathrm{HO}^{\bullet}$ mechanism was proposed.

\section{Conflict of interest}

The authors declare no competing financial interest.

\section{Acknowledgements}

This study was financially supported by the National Natural Science Foundation of China (41572213). We are also thankful for the support provided by the Key Project of National Natural Science Foundation of China (41530636).

\section{References}

1 C. Walling, Fenton's reagent revisited, Acc. Chem. Res., 1975, 8, 125-131.

2 A. Romero, A. Santos and F. Vicente, J. Hazard. Mater., 2008, 162, 785-790.

3 C. Walling and A. Goosen, J. Am. Chem. Soc., 1973, 95, 29872991.

4 B. H. Bielski, D. E. Cabelli, R. L. Arudi and A. B. Ross, J. Phys. Chem. Ref. Data, 1985, 14, 1041-1100.

5 A. S. Stasinakis, Global NEST J., 2008, 10, 376-385.

6 E. Chamarro, A. Marco and S. Esplugas, Water Res., 2001, 35, 1047-1051.

7 R. J. Watts, Biorem. J., 1992, 2, 413-425.

8 R. J. Watts and S. E. Dilly, J. Hazard. Mater., 1996, 51, 209224.

9 R. J. Watts and A. L. Teel, J. Environ. Eng., 2005, 131, 612-622.

10 B. Francesco, E. Bernd, M. C. M. Gribnau and E. J. Baerends, Chemistry, 2003, 9, 3436-3444.

11 R. J. Watts, M. K. Foget, S. H. Kong and A. L. Teel, J. Hazard. Mater., 1999, 69, 229-243.

12 P. Xu, G. Achari, M. Mahmoud and R. Joshi, Pract. Period. Hazard., Toxic, Radioact. Waste Manage., 2006, 10, 19-27.

13 G. Chen, G. E. Hoag, P. Chedda, F. Nadim, B. A. Woody and G. M. Dobbs, J. Hazard. Mater., 2001, 87, 171-186.

14 M. P. Granados, G. M. Salido, A. González and J. A. Pariente, Biochem. Cell Biol., 2006, 84, 39-48.

15 T. Schmidtke, D. White and C. Woolard, J. Hazard. Mater., 1999, 64, 157-165.

16 S. J. Liu, B. Jiang, G. Q. Huang and X. G. Li, Water Res., 2006, 40, 3401-3408.

17 D. P. Cassidy and R. L. Irvine, J. Hazard. Mater., 1999, 69, 2539. 
18 A. C. Air and C. Water, in US Environmental Protection Agency, Washington DC., 1999.

19 A. Northup and D. Cassidy, J. Hazard. Mater., 2008, 152, 1164-1170.

20 B. W. Bogan, V. Trbovic and J. R. Paterek, Chemosphere, 2003, 50, 15-21.

21 I. I. Vol'nov and A. W. Petrocelli, Peroxides, superoxides, and ozonides of alkali and alkaline earth metals, Plenum Press, New York, 1966.

22 H. F. Wang, Y. S. Zhao, T. Y. Li, Z. Chen, Y. Wang and C. Y. Qin, Chem. Eng. J., 2016, 303, 450-457.

23 M. Arienzo, Chemosphere, 2000, 40, 331-337.

24 A. Goi and M. Trapido, J. Adv. Oxid. Technol., 2010, 13, 50-58.

25 A. C. Ndjou'ou and D. Cassidy, Chemosphere, 2006, 65, 16101615.

26 X. Zhang, X. Gu, S. Lu, Z. Miao, M. Xu, X. Fu, Z. Qiu and Q. Sui, J. Hazard. Mater., 2015, 284, 253-260.

27 G. V. Buxton, C. L. Greenstock, W. P. Helman and A. B. Ross, J. Phys. Chem. Ref. Data, 1988, 17, 513-886.

28 C. Liang and H. W. Su, Ind. Eng. Chem. Res., 2009, 48, 55585562.

29 A. L. Teel and R. J. Watts, J. Hazard. Mater., 2002, 94, 179189.

30 M. Xu, X. Gu, S. Lu, Z. Qiu and Q. Sui, Ind. Eng. Chem. Res., 2014, 53, 1056-1063.
31 N. Wang, L. Zhu, M. Lei, Y. She, M. Cao and H. Tang, ACS Catal., 2011, 1, 1193-1202.

32 X. Fu, X. Gu, S. Lu, M. Xu, Z. Miao, X. Zhang, et al., Chem. Eng. J., 2016, 285, 180-188.

33 E. Neyens and J. Baeyens, J. Hazard. Mater., 2003, 98, 33-50. 34 S. Fukuchi, R. Nishimoto, M. Fukushima and Q. Zhu, Appl. Catal., B, 2014, 147, 411-419.

35 M. Luo, D. Bowden and P. Brimblecombe, Appl. Catal., B, 2009, 85, 201-206.

36 T. R. Gordon and A. L. Marsh, Catal. Lett., 2009, 132, 349354.

37 Z. Tao, Y. Li, J. Jing, F. S. Wong and X. Lu, Sep. Purif. Technol., 2008, 62, 551-558.

38 L. Xu and J. Wang, Appl. Catal., B, 2012, 123, 117-126.

39 H. Wang and J. Wang, Appl. Catal., B, 2009, 89, 111-117.

$40 \mathrm{H}$. Wang and J. Wang, Electrochim. Acta, 2008, 53, 6402-6409.

41 W. Chu, C. Y. Kwan, K. H. Chan and S. K. Kam, J. Hazard. Mater., 2005, 121, 119-126.

42 E. Brillas, J. C. Calpe and J. Casado, Water Res., 2000, 34, 2253-2262.

43 C. Badellino, C. A. Rodrigues and R. Bertazzoli, J. Hazard. Mater., 2006, 137, 856-864.

44 C. Chen, P. Lei, H. Ji, W. Ma, J. Zhao, H. Hidaka and N. Serpone, Environ. Sci. Technol., 2004, 38, 329-337. 